\title{
Charles Dickens' Critical Realism in David Copperfield
}

\author{
Xiaohui Huang \\ College of Law and Politics, Zhejiang A\&F University, Lin'an,Hangzhou of Zhejiang Province,
} 311300

Keywords: critical realism; expose and criticize; significance

\begin{abstract}
Charles Dickens, a great English writer after Shakespeare, is the most achieved representative of the English critical realism literature of the 19th century. Dickens is immortal, and his works vividly reproduce the social conditions of Victorian England.

By making an analysis of the historical settings, especially the concrete personage images, and identifying the critical realism in the novel, this thesis aims to reveal and criticize the social issues in the early Victorian era in the middle of the $19^{\text {th }}$ century.

The hero David's grief at separation and joy in union in David Copperfield reveals the true nature of the society from multi-level aspects. This typically shows the corrosion of money on marriage, family and society and exposes the evils of money. To expose and criticize the social problems in the mid of nineteenth century Queen Victoria era, we reveal the hidden Victoria beauty of the curtain Society to find out the real social appearance in the works. So the study of the details of the critical realism in David Copperfield has the special significance on the research of Dickens's emotional creation and understanding of the society at that time.
\end{abstract}

\section{Introduction}

Charles Dickens was the first author who had written of the poor with fidelity and sympathy and particularly famous for his vivid comic characterizations and social criticism. His works were also famous during Victorian age and among the great classics in all fictions.

He wrote many works about the society in the $19^{\text {th }}$ century, among which David Copperfield was one of the most important novels and his favorite. The novel implied the author's unusual life experience. Meanwhile, David Copperfield destiny symbolized the middle-class intelligentsia questing for development in the $19^{\text {th }}$ century in British society.

Details of critical realism in the novel expose and criticize profoundly the reality, which shows the strong dissatisfaction and rebellion towards reality. Their criticism was against the evils of capitalist society and atrocities, ugly money relations and degradation characters in the society and the hypocritical morality. Critical realism not only arouses suspicion and concern of people about the order of reality, but also plays a huge role in the progress of the society and the development of contemporary world literature.

\section{The Sources for Critical Realism}

\section{A. The rise of critical realism}

In the western literature, critical realism is inheritance and development of the realism tradition. It is especially formed a literary thinking and creative way in Europe in the 19th century. 
To know more about critical realism, this paper will make a brief introduction to the background and the basic characteristics of critical realism.

1) Basic introduction to critical realism ideology

Critical realism ideological trend has made great achievements in Europe. The great achievements of Europe critical realism uncover the human civilization in the 19th century. There appeared a new literary trend and obtained the preliminary development from the 1820s. Critical realism became the main trend of European literature from 30s to 40s after romanticism. English critical realism of the $19^{\text {th }}$ century flourished in the forties and in the early fifties. In Britain, Charles Dickens and William Makepeace Thackeray represent the interests of small and medium-sized bourgeois at that time to expose and criticize sin and corruption of the capitalist social reality. Others are Bronte sisters, Elizabeth Gaskell, George Eliot, and Thomas Hardy. The novelists exposed and criticized the corrupted society mercilessly. They are generally known as critical realists. The greatest English realist of the time was Charles Dickens.

2) The basic characteristics of critical realism literature

The critical realism literature in nineteenth century, is a splendid page in the bourgeois literary history and also an important heritage in the treasure trove of the world literature. Critical realism shows all aspects of social life and reveals the contradiction of reality in considerable depth. In their works, we can see the collapse of the feudal society and the rise of capitalism. We can also see oppressive serfdom and cruel capital exploitation. They particularly expose and criticize the capitalist system, which is widely involved in various fields. This causes the people's suspicion and dissatisfaction to the existing order, so it has great social significance.

\section{B. The introduction to Charles Dickens}

Dickens was the main representative of realism literature of the 19th century. Contemporary British writer George Orwell said: “ Among the British writer, there is no one better than Dickens in depicting childhood”.Therefore, it’s necessary to know more about Dickens. Dickens' special life experience, provides rich nutrients and material for his writing. Dickens was born in February 7, 1812, at Landport, Portsmouth. His father was a clerk of Naval Ordnance Department. Because the family burden is heavy, the whole family were in debt and had been put in prison. As he was the second of eight children, 11-year-old Dickens had to work at a shoe polish workshops as an apprentice. Dickens was able to return to school after a small legacy helped release his father from prison. He was an avid reader and spent much time in the reading room of the British Museum and learnt short-hand.

At the age of fifteen Dickens began working as an office boy for a law firm. He taught himself and by 1828 he became a reporter for courts of Doctors's Common. The dull routine of the legal profession never interested him, so he became a newspaper reporter for the Mirror of parliament, the True Sun, and finally for the Morning Chronicle. By the age of twenty, Dickens was one of the best parliamentary reporters in all England. All the bitterness and all kinds of hardships in the childhood life he experienced left a permanent record in his heart. His attention to " little people" in the bottom of society is to start from his childhood. We have to admit that life experience of Dickens has a far-reaching impact of literary creation. These bitter days remained in his memory and later found expression in his works. He has a lot of works which through the "small character" to show the reality of life, and reveal social cruelty. we can see that childhood 
experience of Dickens makes the creation of his "David Copperfield", and make it has strong appeal.

\section{The introduction to David Copperfield}

Of all the Dickens' novels, David Copperfield reflects the events of Dickens' own life the most. David's early suffering was adequately compensated with a rich, happy marriage and a successful literary career, just like Dickens himself, and the world is still full of hope and sunshine. The novel's detailed narration was also worth mentioning, which gave the work a truthfulness to the real life.

David Copperfield is the eighth novel written by British novelist Charles Dickens. From 1849 to 1850 years, it was published in 20 parts monthly with the first person narrative tone, which melts into the life experience of the author. Here Dickens made good use of his own life experience to attack the social evils of the time, the miseries of child-labor, the tyranny in schools, the debtors' prison, as well as the cruelty and immortality and the treachery that were prevalent in Victorian England. Thus the novel was not merely a personal record, but a broad picture of the $19^{\text {th }}$ century England.

\section{A Satirical Portrayal of the Bourgeois Society}

\section{A. The prejudice against the poor due to the caste system}

Different characters in the novel represent different classes and show us the wide gulf between the classes in Victorian England. Emily is quite aware of the difference between her class and David's when he first meets her. When they are at the seaside, he notes that both of them are orphans, but she calls his attention to one important difference: they have different status and lifestyles. Emily means that her parents worked hard to maintain minimal standard of living, while David's parents had some inherited wealth. Even at such a young age, Emily understands how money can radically affect one's life. Later, when she hopes to become a lady by marrying Steerforth, she is forced to realize how entrenched economically based prejudices can be.

David is also aware of class divisions and is distressed when he faces the possibility that he will never regain entry into the middle class. He is left broken-hearted he does not associate with the other boys at the warehouse, thinking them beneath him, When David's fortunes change, he enjoys his status as a gentleman and is desperate to keep people from knowing how poor he had once been.

David's attitudes toward the lower class, however, are much different from the Steerforth's. A huge contrast developed between the higher and the lower social classes, and this contrast becomes evident in the novel in the Steerforth family and the Peggotty family. James Steerforth belongs to a higher social class. His family is very wealthy and he is described as "good as his word" and "very good-looking”. Peggotty’s family are lower-class people, simple fishermen and workers. Dickens shows the clash of the classes and reveals the unalterable reality.

\section{B. The miserable childhood under the suppression of the cruel stepfather}

Although David's father was dead after he was born, he also led a very happy life with his mother and Peggotty. However, David's childhood idyllic is destroyed by the marriage of his 
widowed mother to Mr. Murdstone. Mr. Murdstone makes clear that he is the boss in the house, He suppresses David's mother by expecting her to be firm towards his son, and he suppresses David with physical cruelty. He is suffering from his cruel treatment and sent away to a boarding school. After the death of his mother, he has almost nobody in the world to turn to and his father-in-law sends him immediately to work in his own warehouse called "Murdstone and Grinby” instead of sending him to school. David lives without adequate food and clothes from then on and it's no longer possible for him to develop freely. He reveals his secret agony of his soul and no words can express his feeling as he sinks into this companionship. We can see he suffered not only from physical, but also from mental destruction and psychological damage after he was thrown away at such an age. The lack of love and affection in the society should be criticized.

David Copperfield is a representative of this period. The industrial revolution creates a series of miracles, behind the miracles, however, it contains too much bitterness. The great wealth of the industrial revolution should be benefit for the children first, but more children spend their study life in factories. They don't get the knowledge they should obtain, but experienced the vicissitudes of life they shouldn't have in the world. They suffered from physical, mental, destruction and psychological damage at such an early age.

\section{The destructive effect of children's education system}

Salem House can be seen as a representative of many schools at that time. So the following is common in educations at that time. When David arrived at school, he described: "Scraps of old copy-books and exercises litter the dirty floor. There is a strange un-wholesome smell upon the room, like mildewed corduroys, sweet apples wanting air, and rotten books. There could not well be more ink splashed about it.” All these reveal the bad conditions for students studying. No body cares the environment and does some improvement for them.

Mr. Creakle, the principle and owner of Salem House, profits from this institution. However, the teachers suffer from poverty and bad living conditions. All these is fact and We can see from the describe of boots and clothes of Mr. Mell. Obviously, the capitalist system infiltrated not only workhouses, but also the educational system. At the same time, educational methods and teacher's ethics was also criticized. Thus, David is to wear a sign on his back that reads "Take care of him, He bites. " This is a way to educate him, however, he suffers from a great mental strain. These methods result in psychological vulnerability and mental disorder instead of achieving the aim of teaching. Dickens want to show us it destroys progress in the inner world of students.

Child's education problem is not only the quality of labor force and a educational problem, but also social problems. The level of moral and cultural is low,which is not synchronized with the speed of economic and social development. At this time, it needs to pay more attention to the disadvantaged groups, and provides possibilities for their development. Otherwise, it will damage the sustainability of social development.

\section{Women's images for emancipation}

Women were confined to the classes in which they were born during the eighteenth and nineteenth centuries, unless their fathers or husbands moved up or down in the social hierarchy. The strict rules for each social class defined women and determined their lives. Women in the upper classes had the leisure to become educated; however, like their counterparts in the lower 
classes, upper-class women were not expected to think for themselves and were not often listened to when they did. Urges for independence and self-determination were suppressed in women from all classes. The strict social morality of the period demanded that middle-class women and those in classes above exhibit the standards of polite femininity, culminating in the ideals of marriage and motherhood.

David Copperfield both reinforced and challenged the period's attitudes toward women. Most female characters, however, operate within the confines of the middle class. Miss Trotwood's quick mind and independent spirit was tolerated because she was considered eccentric and a widow. Among the many female characters the reader gets to know throughout the story of David Copperfield's life, there are mainly three that stand out among all the other women in the novel and who play a central role in the life of the main character. Those women are Dora Spenlow, the first wife of David Copperfield, Agnes Wickfield, Copperfield's childhood friend and second wife and Betsey Trotwood, David's Aunt and permanent companion from childhood on. Those women all have in common that they play a pivotal role in the main character's life, but each of them represents a different kind of woman.

\section{The Impact of Critical Realism}

\section{A. The influence of critical realism}

Critical realism literature is the product of capitalist establishment, development, and constantly consolidate period. It widely reflects people's social life at that time, the existence of class relations, reveals the nature and the trend of the development of the society at that time with great value and significance. Critical realism writer, by applying the methods of the thesis and shaping the typical character in typical environment, accurately reproduces the social life and people's mental outlook. Critical realism literary representative writers, representative and typical characters, reflecting the extensive and profound social life are all unprecedented. It reveals the capitalist society in the ruthless economic exploitation and political oppression, reflects the deep misery suffered by working people, reveals the naked money relations between people in the capitalist society. Critical realism shows the collapse of the feudal society and historical process of the rise of capitalist, which has the very high historical value and aesthetic value.

\section{B. The realistic significance of the critical realism literature}

In the commodity economy society, the relationship between money is very important social relation between people whether in capitalism or socialism. The correct understanding, treating and dealing well with the relationship will be conducive to the spiritual civilization construction and social stability. History is a mirror and tapping into the realistic significance of the critical realism literature and playing its role in the literary and artistic creation is undoubtedly an important responsibility of the literary and art workers.And socialist literature develops from inheriting the traditional ethnic culture and absorbing foreign culture essence. Although critical realism tide in a dominant position has ended, but creation technique and thinking of critical realism will affect future generations for a long time.

we should combine the critical realism literary and other creation methods together to shape a unique personality and highly artistic image. But no matter how, the realistic significance of the critical realism literature is big, and we still should draw lessons from and absorbing it. For our 
modern society, something dark and evil in the capitalist society shows us the hardship and bitterness of life. Therefore, we should be more rational toward life rather than the pursuit of impossible things blindly and should restore our most real life.

\section{Conclusion}

Dickens is one of the greatest English critical realism writers. As a world-class master in literature, people admire him, respect him. In addition to superb techniques in his writing style, it is important that he often cherishes a heart of compassion. Besides, he shapes these "little guy"for us living in the bottom of the society with humanitarian feelings.

The novels of Dickens put people in the social contradiction and struggle, reveals various ugly faces of the society, describes the unfortunate fate of female characters, to excavate the good of humanity. Some characters of the novel have exposed the ugly face of money society everywhere. The detailed analysis of critical realism reveals the truth of the society and expresses deep sympathy for the common people on the social darkness. All these reality calls for more attention to the unjust treatment at that time and it has great significance to promote social progress. The novels of Dickens conform to the trend of our times and cater to social mainstream consciousness and he also became the most popular writers of that age. Today, we revisit the classic and it is great for the construction of harmonious society, the construction of socialist spiritual civilization.

\section{References}

[1]Charles Eliot Norton Charles Dickens. North American Review, [J]. 1868(04).

[2]Dickens, Charles, David Copperfield. [M]. Beijing: Foreign Language and Research Press, Oxford University Press, 1997.

[3]Forster, John. The Life of Charles Dickens. [M]. New York: Scribner Vo12, 1905.

[4]Slater, Michael. Dickens and Women[M]. Stanford: Stanford University Press, 1983.

[5]Smith, Grahame. Charles Dickens: A literary Life [M]. New York: St.Martin’s, 1996. 